\title{
TRIANGLE OF DYNAMICS FACTORS IN INTER-ORGANIZATIONAL NETWORKS
}

\author{
Aleksandra SUS $\mathbb{D}^{*}$, Michał ORGANA* \\ Department of Strategy and Management Methods, Faculty of Management and Computer Science, \\ Wrocław University of Economics, Komandorska 118/120, 53-345, Wrocław, Poland \\ *E-mails: aleksandra.sus@ue.wroc.pl; michal.organa@ue.wroc.pl
}

\begin{abstract}
Purpose - the main scientific purpose of this article is to conceptualise the categories of dynamics of interorganisational networks strategy. The scientific problem presented in the article concerns initially identified connections between three major elements (based on literature studies and authors' previous experiences), describing the dynamism of the strategy as mentioned above. Those elements were named by the authors as the Triangle of Dynamics Factors (TDF), and are (1) propensity of taking the risk and real ability to accurately assess opportunities, (2) skills, and processes of opportunities identification, creation, and exploitation, as well as (3) leadership skills of contemporary managers. Basing on those connections, the article concerns on clarifying research hypotheses in the areas of the three mentioned differentiating factors.
\end{abstract}

Research methodology - in order to achieve the main goal of the article both quantitative (survey research) and qualitative (case study) methods were chosen for future research.

Findings - the conducted research is focused on positioning previously mentioned categories in the micro-scale strategy, as well as on determining variables constituting the dynamics of inter-organisational networks strategies. The article presents research hypotheses that will be verified.

Research limitations - the limitations are primarily related to a variety of factors influencing the dynamics of interorganisational network strategies, observed both inside and outside the networks. The article focuses on those factors that decision-makers in networks can influence, which is tantamount to omitting most factors within the networks' environment. At the same time, the article focuses on selected types of inter-organisational networks - both decentralised and centralised. The article is conceptual; therefore, it does not contain the results of empirical research directly oriented on all three identified factors, which is its specific limitation. Partial results of the previously conducted research indicated in the article relate only to one of the identified elements. It is the area of skills, and processes of opportunities identification, creation, and exploitation.

Practical implications - the practical business implications concern mostly the necessity of organisational adaptation to changing environmental conditions, the imperative of being flexible and striving for the success by inter-organisational networks. The article identifies those factors being under the actual influence exerted by networks' representatives.

Originality/Value - this article is the authors' third joint work, and hitherto in the examined literature, there were no publications dedicated to the study of strategy dynamics and dynamism of the inter-organisational networks' strategy, researched in the triad: risk - opportunities - leadership. This creates a wide interpretative and research area for the indicated topic.

Keywords: strategy, dynamics factors, opportunities, inter-organisational networks.

JEL Classification: L21, L22, L25.

Conference topic: Contemporary Organizations Development Management.

\section{Introduction}

The trend of strategising in contemporary strategic management is associated with the anthropomorphisation of market entities, and thus the growing importance of human being in achieving goals and reaching successes in companies. It is not the organisation that generates profits, but the people employed in their units and organisational structures. Thus, the way of formulating the strategy changes - towards the micro-trend, building a new ecosystem of enterprises, in which man and his features determine the success or failure of business entities. An open strategy is associated with 
the micro-trend concept, which also emphasises the relationship between the organisation and market entities. The levels of the relationship between micro-trend, open strategy and the strategic ecosystem are presented in Figure 1.

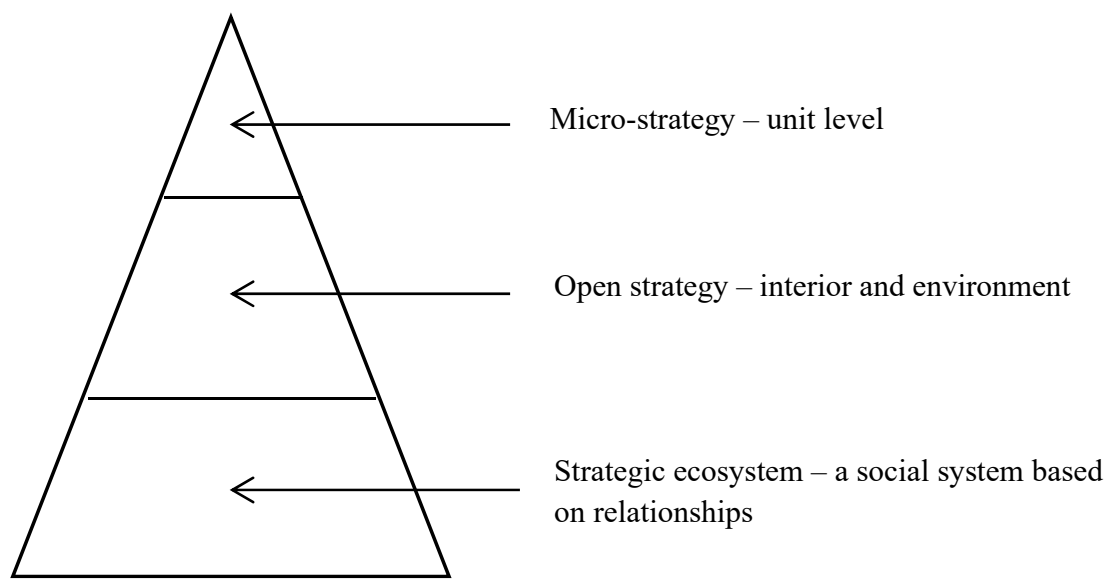

Figure 1. Strategic openness - relationship levels (source: Sus A. (2017). Mikro - i otwarta strategia. Kontekst ekosystemu /Micro - and open strategy in an ecosystem context/. Organizacja i Kierowanie / Organization and Management/, no. 2, 2017, p. 80)

The micro-phenomenon is a consequence of the resource wave, which paid attention to human resources and the potential associated with them. It has been popularised thanks to researchers focused around SAP-IN ${ }^{1}$. The formulation of strategy at the micro level (strategizing) refers to the classic approach, according to which it is a process inseparably connected with its implementation ${ }^{2}$, constructive in both stages, which is driven by the activity of top-level personnel. This definition deliberately underlines the role of the human factor, but it does not mean that it ignores the other aspects of the strategy creation process. Contemporary literature focuses on the approach based on the "pixels of managerial influence" (Jarzabkowski, 2008), slightly more spectacularly accenting the social determinants of this process. "Strategy in accordance with this approach, is not something that the organisation has, and something that its members do" (Johnson, Melin, \& Whittington, 2003) Operationalization of the strategy is behavioural, determining its dynamics and social (Jarzabkowski, Balogun, \& Seidl, 2007). The strategy evolves over time and is no longer a set of separate decisions, but a set of undefined managerial behaviours embedded in social conditions (Jarzabkowski, 2008). This argument also makes it necessary to pay attention to the relational determinants of strategy and strategic openness.

The significance of the resource approach in contemporary strategic management is particularly emphasised by the authors' research (Sus, 2019) - which was an inspiration for further empirical explorations. At the turn of 2017 and 2018, research was conducted on a group of 996 deliberately selected enterprises. Pilot studies preceded the basic research, the aim of which was to verify the questionnaire. The research aimed to identify the features that distinguish the logic of mutual adjustment of opportunities and real strategic options - which is not the subject of this study. Nevertheless, during the analysis of the research results, the focus point moved to the 3 leading elements that were presented in further parts of this study, and to which the authors included: risk perception, exploitation of opportunities and leadership skills. The research was based on nomothetic methodology, using purposeful sampling and a standardised research tool (a research questionnaire). The research techniques that constituted the core of the research were Computer Assisted Personal Interviews (CAPI) and interviews conducted via the Internet (Computable Assisted Web Interview - CAWI) - in general, $87 \%$ of the research respondends.

During the research, three strategic logics were analysed - positioning, the influence of competences and seeking opportunities. The characteristics of the research sample are presented in Table 1.

One of the research elements were the determinants of strategy creation in 3 logics, which was verified on a sample of 121 enterprises (results from one company were eliminated due to the lacks in the questionnaire). Interestingly, as a criterion for choosing an opportunity, the majority of respondents (67\%) indicated a possibility to build a competitive advantage based on resources - including human resources - which forced association with the importance of leadership in the processes of generating strategy dynamics. Next, $52 \%$ of respondents showed that using opportunities would minimise strategic risk - taking the form of losing market position, as well as key clients. This result, in turn, directed attention towards the risk management strategy and the perception of this category. $42 \%$ of respondents

\footnotetext{
Strategy-as-Practice-International Network is an international network of about 3,000 researchers and practitioners from around the world, whose primary goal is to clarify the phenomena and laws regulating contemporary strategic management from the micro point of view - the individual perspective of the entity.

2 In this way, the strategy does not separate the planning phase from implementation - it takes on the characteristics of a dynamic, ad hoc response to existing market situations. The company is also actively taking advantage of opportunities that are not yet included in the strategy. It is worth to consider, if it is then possible to talk about a planning model emerging in the literature, focused on the use of opportunities (planning by opportunities). If so, another vital issue is to think about changing the nomenclature of planning categories, especially planning the future if decisions are made in real time.
} 
pointed to the implementation of the company's strategy based on the consistent use and generation of opportunities from within the company and the environment. These results proved the importance of taking into account the opportunities within the business strategy, and not only the stable and constant implementation of the assumed strategic plans. Besides, in 62 cases a significant correlation was found between decision-making closely related to the analysis of opportunities and the managerial abilities to capture and use opportunities and their impact on the strategic development of the company. Importantly, the majority of companies analysing opportunities (59\%) shows the ability to use them in strategic development. The research also correlated questions about the use of opportunities and making final choices between them (see Table 2).

Table 1. Characteristics of the research sample (source: own elaboration)

\begin{tabular}{|c|c|c|c|c|c|}
\hline Factor & Number of organisations & $\%$ & Factor & Number of organisations & $\%$ \\
\hline \multicolumn{3}{|c|}{ Size } & \multicolumn{3}{|c|}{ Share of foreign capital } \\
\hline Micro & 56 & 46 & No & 103 & 84 \\
\hline Small & 42 & 36 & Yes & 19 & 16 \\
\hline Middle & 12 & 9 & In total & 122 & 100 \\
\hline Big & 12 & 9 & \multicolumn{3}{|c|}{ Phase of life cycle } \\
\hline In total & 122 & 100 & Stabilisation, maturity & 71 & 58 \\
\hline \multicolumn{3}{|c|}{ Business profile } & Fast growth & 33 & 27 \\
\hline Production & 38 & 31 & Entering the market & 7 & 6 \\
\hline Services & 74 & 60 & Declining & 3 & 2 \\
\hline Trade & 10 & 9 & Difficult to determine & 8 & 7 \\
\hline In total & 122 & 100 & In total & 122 & 100 \\
\hline
\end{tabular}

Table 2. Exploiting opportunities and making choices between them (source: own elaboration)

\begin{tabular}{|c|c|c|c|}
\hline & & \multicolumn{2}{|c|}{$\begin{array}{l}\text { Have you ever had situations in your business activity in which } \\
\text { you had to make choices between emerging opportunities? }\end{array}$} \\
\hline & & Yes & No \\
\hline \multirow{2}{*}{$\begin{array}{l}\text { Does your company, when making deci- } \\
\text { sions, analyse emerging opportunities? }\end{array}$} & Yes & 97 & 8 \\
\hline & No & 21 & 18 \\
\hline
\end{tabular}

A significant correlation $\left(\chi^{2}=28,54 ; p<0,0001\right)$ indicates that 21 enterprises do not undertake intentional actions involving the analysis of emerging opportunities. However, respondents - at various positions in the surveyed organizations - indicated that they made choices between them, which indicates the use of Optional solutions, as well as the application of an approach with regard to evidential actions (which should be treated as a response to emerging opportunities), and not a static, traditional variant. Presented research results form the basis for theoretical considerations of this study.

Taking into account the three analysed areas, i.e., propensity to risk, identification, creation and use of opportunities, as well as individual leadership traits, attention was drawn to the fact that the features do not determine them or distinguishing features of the organisation, but by individual persons employed. In this way, the main point of concentration became the micro-trend and strategising - related to it in the analysed areas. The inter-organisational networks both decentralised and centralised - became an interesting object of research for utilitarian reasons and in relation to the research gaps identified in the literature (Czakon, 2012; Niemczyk, 2007; Ratajczak-Mrozek, 2013).

The micro-trend determines nomenclature changes, which further accentuates the concentration of attention to individual activities (micro-actions), micro-determinants (micro aspects) and micro-basics (micro foundations). The foundation of the practical and theoretical approach are three elements and related questions (Jarzabkowski, Balogun \& Seidl, 2007):

- Who is a strategic actor, shaping the practice through the ways of his actions (practitioners)?

- What is the basis of their strategic decisions (practices)?

- How are strategic decisions (praxis) made?

The focus point of this study is a product of these considerations, as well as the current considerations of the authors of the study related to the dynamism and dynamics of the inter-organisational networks' strategy. Previous theoretical works allowed to identify the basic conceptual categories that are the foundation for the formulated research questions and the triangle of dynamics factors of the contemporary strategy, to which the authors included: risk-taking 
processes (what underlies dynamic strategic decisions?), exploiting opportunities (how strategic decisions are undertaken?) and leadership (who is a strategic actor and what features make him stand out?). These categories determine the dynamism and dynamics of the strategy. The principal object of the research, both theoretical and practical, are decentralised and centralised inter-organisational networks - in the sense of decisional centralisation, which means without or with a strong decisional centre. The planned research will mostly concern the Polish market. The study presents a further series of theoretical considerations and research proposals in the analysed areas. Except the main target indicated in the abstract, the authors also focus on starting a discussion in the literature on the dynamism and dynamics of the strategy of inter-organisational networks.

\section{Conceptualisation of basic categories}

Authors defined the activity of companies in relation to the variability of their environment as the strategy dynamics (SD). According to theoretical findings (Sus \& Organa, 2019), such a strategy is the result of an incremental decisionmaking model and co-revolutionary symbiosis between participants of the market game, for which the existing plan is a determinant of strategic goals, but the implementation of strategic objectives includes active identification, creation, and exploitation of opportunities. The strategy dynamics takes a gradual form, and the authors based on studies of the subject literature defined three initial levels of it: total, partial and zero (especially interesting should be research results in the area of partial exemplification of dynamics, and in particular its optimal levels for specific types of inter-organisational networks). The strategy dynamics is a derivative of the dynamism of strategy, which results from the previously asked questions in the area of micro-arrangements of the strategising approach. Moving around in a maze of factors actively influencing the strategy of inter-organisational networks, the authors identified 3 key areas of interest 3 main groups of factors. These factors are called the triangle of dynamic factors that are the antecedents of the dynamism of the strategy, and then the strategy dynamics. They include:

- Propensity to risk, which is connected to the real ability of opportunities assessment - it can be considered through elements of the risk exposure calculator () i.e. formal vs informal strategies of risk-taking introduced in the company, recovery programs, conflicts and crises, as well as dealing with them, concentration on achieving results, company's expansion pace, deficiency of experienced employees, circumstances of internal competition, managerial resistance to deal with negative information, transactions' complexity issues, lack of performance indicators, degree of decisions decentralization, rewards for risk-taking attitudes.

- Taking advantage of opportunities - skills and processes of especially in the view of identification, creation and exploitation of opportunities (necessary skill and processes), including possessed knowledge, creativity, human capital (Ucbasaran, Westhead \& Wright, 2009), alertness (Baron, 2006), responsiveness (Zaheer \& Zaheer, 1997), entrepreneurial skills (Muzychenko, 2008), learning through experiments (Corbett, 2007).

- Strategic leadership - which is perceived as a dynamic category, especially within circumstances of interorganisational networks, changing through subsequent stages of their development.

Therefore, it was assumed that the dynamism and strategy dynamics are categories:

- Located within strategising approach - directly affected by units managing inter-organisational networks, as well as those operating in the networks.

- Determined by the triangle of dynamics factors, with the assumption of complementarity of the individual factors, as well as the openness of the presented set - it may turn out during pilot studies that essential aspects have been omitted; thus the possibility of extending the described triad is allowed. The key criterion during the selection of factors is their direct impact on strategy dynamics optimisation.

Relations between mentioned categories are shown in Figure 2.

One of the most critical elements of the planned research will be the utilisation of the measuring scale of the centralisation degree of studied inter-organisational networks, in the sense of decisional centralisation, which means the concentration of the strategic decision-making process. In the analysed context, the following research hypotheses mean:

- H1: The dynamics of the strategy determines the type of inter-organisational network - the research assumption adopted as a true hypothesis: more centralised network systems show a higher level of the strategy dynamics.

$-\mathrm{H} 2$ : Changes occurring in the network environment, as well as changes in its individual internal components, cause an increase in the network's dynamics.

- H3: The network's dynamics is determined by risk propensity, identification/creation and use of opportunities, as well as managerial leadership skills.

- H3A: More centralised network systems have an optimal risk propensity level.

- H3B: A higher level of opportunities identification or creation and their use is characteristic for more decentralised network systems. 
- H3C: Clearer manifestations of leadership are noticeable in more centralised inter-organisational networks.
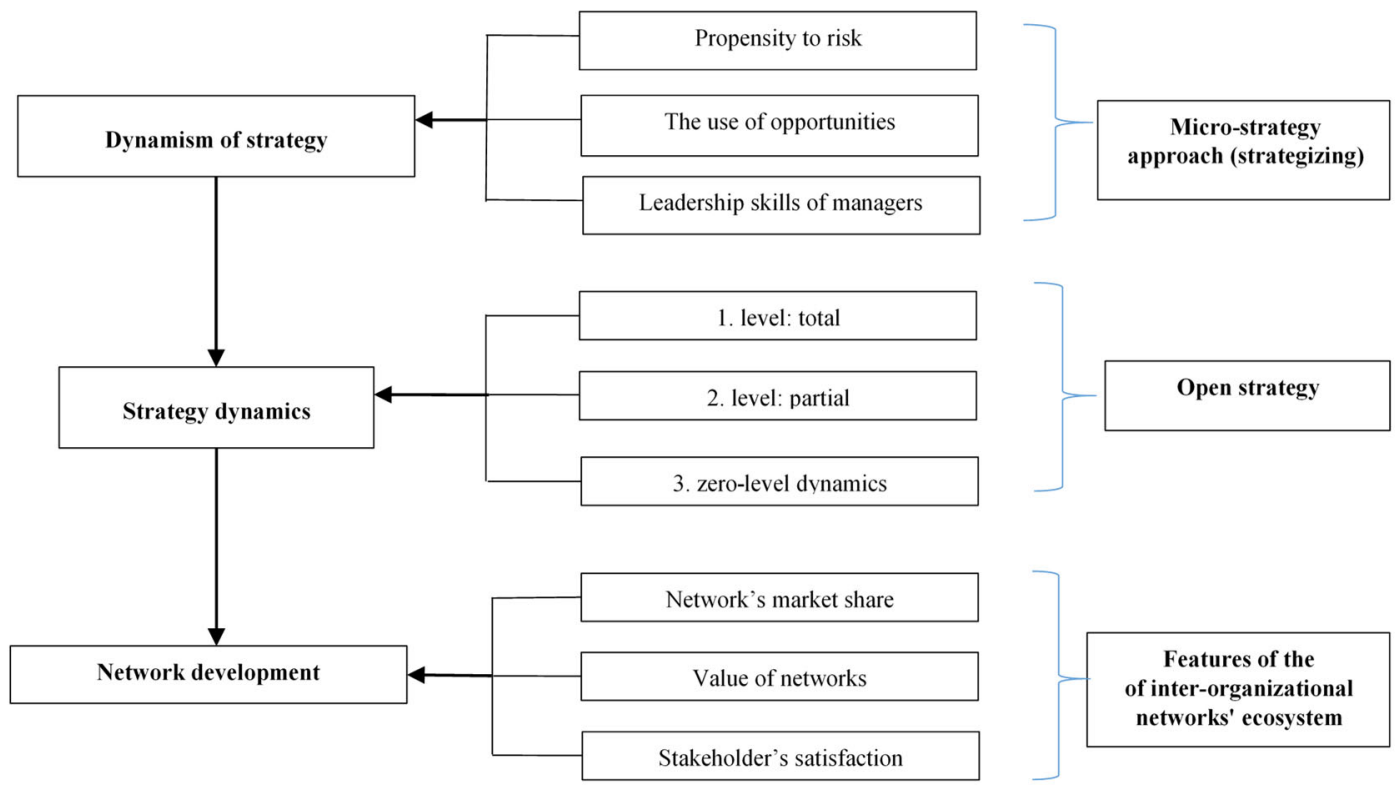

Figure 2. The original model of empirical research on the dynamism and strategy dynamics (source: own elaboration)

Positive verification of H3A-H3C hypotheses should indicate the importance of the micro-trend concept in the strategic management process of inter-organisational networks - thus, identifying further research directions within the discussed area. It becomes essential to determine to what extent the micro-approach to managing inter-organisational networks (regardless of their type) will determine the development of the analysed network. This is especially important if the following hypothesis is confirmed: H4: Higher strategy dynamics results in more significant development of the inter-organisational network. The adopted research hypotheses focus on three main issues: leadership, risktaking and exploiting opportunities that are the consequence of their identification or deliberate creation on the contemporary markets.

\section{Components of the H3A hypothesis: risk measurement in network systems}

Most often the network risk is identified with the attributes of an "entangled organization" (Witt de \& Meyer, 2007), which involves the risk of relationships in the context of the risk of independence loss (risk of dependence, the socalled hold-up risk) and the risk of spillover (Nooteboom, 2005). Network risk may also result from the asymmetry of various flows - financial, information and formal - related to the flows of rights and responsibilities between entities in the network (Gnyawali \& Madhavan, 2001). The opportunistic behaviour of the network partners is also an important source of risk, in particular, those related to the transmission of distorted information, appropriation of technologies and employees, or the supply of lower quality products than the contract between the network partners set (Parkhe, 1993). Besides, the network risk is also associated with an increase in transaction costs related to the growing number of network participants, the danger of errors in the information management process or an attempt to limit the independence of weaker network partners (Hatch, 2002).

When analysing the risk-taking processes in the context of the strategy's dynamics of the inter-organisational network strategy through the prism of strategising approach, one should pay attention to individual characteristics. Therefore, the authors have attempted to use elements of the Risk Exposure Calculator tools, the purpose of which is to identify the probability of situations that may jeopardise the implementation of the network's strategy. The inclination to risk is assessed on a 5-point scale, and risk factors were qualified according to R. Simons into three groups: related to growth and development, organisational culture and information management. These groups, together with the proposed hypotheses, are presented in Table 3.

Using the indicated tool, it becomes possible to determine in which of the three possible risk areas an interorganisational network can be located, namely: in the danger zone, warning zone or security zone. Optimum risk propensity level regards the first of these zones, and the authors claim that such a situation will be rather a distinction of centralised network systems. 
Table 3. Selected factors determining the risk propensity level in network systems and partial hypotheses assigned to them (source: own elaboration based on Simons, 1999)

\begin{tabular}{|l|l|}
\hline \multicolumn{1}{|c|}{ Factor } & \multicolumn{1}{c|}{ Proposition of the hypothesis } \\
\hline $\begin{array}{l}\text { Risk related to the growth and development of the inter-organisational } \\
\text { network, caused by setting too ambitious goals for the network and pres- } \\
\text { sure to achieve the assumed results, strong network expansion, employ- } \\
\text { ing a large number of inexperienced employees. }\end{array}$ & $\begin{array}{l}\text { H3A1: more centralised network systems have a } \\
\text { lower risk connected to growth and development. }\end{array}$ \\
\hline $\begin{array}{l}\text { Risk related to organisational culture, which is associated with the re- } \\
\text { warding of innovation and entrepreneurship by undertaking high risk, } \\
\text { blocking the flow of negative information about the market situation and } \\
\text { internal competition between network system employees. }\end{array}$ & $\begin{array}{l}\text { H3A2: lower risks associated with organisational } \\
\text { culture are demonstrated by more centralised net- } \\
\text { work systems }\end{array}$ \\
\hline $\begin{array}{l}\text { Risk related to information management that may be caused by the com- } \\
\text { plexity of market transactions concluded by the network, shortcomings in } \\
\text { data flow control systems and taking too high risks by individual network } \\
\text { elements - in isolation from the global network strategy. }\end{array}$ & $\begin{array}{l}\text { H3A3: lower risks associated with information } \\
\text { management are demonstrated by more centralised } \\
\text { network systems }\end{array}$ \\
\hline
\end{tabular}

Functioning within the network is also associated with the openness of cooperation between its elements, which in turn determines the trust, loyalty and credibility of the network (Chrisidu-Budnik, 2011). The given categories are impossible to achieve in a situation of high risk on the side of factors identified by R. Simons, which were used to describe the dynamism and strategy dynamics of inter-organisational networks.

\section{Components of the H3B hypothesis: indicators of the use of opportunities in network systems}

The processes of using opportunities are described in the literature using a variety of variables and distinctions, e.g. prior experiences, personal disposition, changes in the environment, and their impact in the opportunity process (Gaglio \& Katz, 2001; Shepherd \& DeTienne, 2005; Tripsas, 2008). Their accumulation results in an analytical attempt to capture them in a possibly condensed form. Such a proposal is provided in Table 4. The antecedences of using opportunities considered as effects of dispute whether they are created or identified - were deliberately omitted. Only key factors were included - those responsible for the quality of this process, dynamics, and frequency, which in turn determines the dynamism of the strategy.

Table 4. Selected factors determining the use of opportunities in network systems and partial hypotheses assigned to them (source: own elaboration based on Kirzner, 1997; Zaheer \& Zaheer, 1997; Alvarez, Barney, \& Anderson, 2013; Eisenhardt, 1989; Shane, 2000; Chandra, Styles, \& Wilkinson, 2009; Butler, Doktor, \& Lins, 2010)

\begin{tabular}{|l|l|}
\hline \multicolumn{1}{|c|}{ Factor } & \multicolumn{1}{|c|}{ Proposition of the hypothesis } \\
\hline $\begin{array}{l}\text { Alertness: the ability of an individual to identify opportunities missed } \\
\text { by others; proactive attention to information, especially those of a re- } \\
\text { lational (private) nature, about the possibilities inherent in the mar- } \\
\text { ket; It involves obtaining information thanks to the highest position } \\
\text { in the network of inter-organizational relations, vigilance is depend- } \\
\text { ent on the scale and frequency of scanning the entities entangled in } \\
\text { the network. }\end{array}$ & $\begin{array}{l}\text { H3B1: higher vigilance occurs in more decentralised } \\
\text { inter-organisational networks }\end{array}$ \\
\hline $\begin{array}{l}\text { Responsiveness: is the rate at which the network reacts to environ- } \\
\text { mental changes; speed or high velocity of strategic decision-making. }\end{array}$ & $\begin{array}{l}\text { H3B2: greater responsiveness occurs in more decen- } \\
\text { tralised network systems }\end{array}$ \\
\hline $\begin{array}{l}\text { Prior-knowledge: previous knowledge related to events that have oc- } \\
\text { curred in the past; resulting from the idiosyncratic nature of percep- } \\
\text { tion/creation and exploitation of opportunities. }\end{array}$ & $\begin{array}{l}\text { H3B3: prior knowledge of economic phenomena } \\
\text { stronger determines the use of opportunities in more } \\
\text { decentralised inter-organisational networks }\end{array}$ \\
\hline $\begin{array}{l}\text { Social networks that are a source of ideas, information and new } \\
\text { knowledge within and between the organisational network. }\end{array}$ & $\begin{array}{l}\text { H3B4: the effectiveness of opportunities usage as a re- } \\
\text { sult of social networks activity is more significant in } \\
\text { the case of more decentralised inter-organisational } \\
\text { networks }\end{array}$ \\
\hline $\begin{array}{l}\text { Creativity, or the ability to perceive reality based on unconventional } \\
\text { thinking, moving away from patterns and seeing relationships be- } \\
\text { tween seemingly different situations. In this way, the environment } \\
\text { and interior become an important source of ideas for the network - } \\
\text { positively correlated with vigilance. }\end{array}$ & $\begin{array}{l}\text { H3B5: more decentralised networks show greater effi- } \\
\text { ciency in creating opportunities than centralised ones } \\
\text { H3B6: more decentralised networks show greater effi- } \\
\text { ciency in using opportunities based on creativity }\end{array}$ \\
\hline
\end{tabular}

Among the factors determining the effectiveness of the processes of using opportunities in literature are also mentioned: entrepreneurial competencies, including the propensity to risk, which occupies a separate position in the 
conducted deliberations, or research on the impact of knowledge and skills on the process of using opportunities. Selfefficacy is also an important factor which positively correlates with vigilance and organisational learning and experimenting processes. The set of factors determining the use of opportunities is an open one, and their diversity and number determine the necessity to select and specify those variables that seem to be fundamental to the effectiveness of capture/creation and exploitation of opportunities.

\section{Components of the H3C hypothesis: features that determine leadership in network systems}

Contemporary literature on the subject of leadership offers many concepts of this phenomenon, with the vast majority referring to the perspective of a single, traditional business organisation. At the same time, concepts presenting combinations of identified features, differentiators, skills, styles, levels or leadership roles dominate in the subject literature. (Palmer, 2010; Goleman, 2006; Williams, 2009; Zenger, Folkman, \& Edinger, 2012). Changing from organisational to network context also requires adjusting the concept of leadership embedded in the realities of various types of cooperation between independent business entities. It is also worth noting that the authors of this article consider leadership as interpersonal influence, determining the set of interactions between the leader and other persons around him. Such a perspective is particularly important because it makes illogical searching for a completely different way for understanding the influence of leadership in the new type of organisational development that networks represent. The context, environment or background of leadership activities change, while the essence of leadership remains unchanged - it is always about the ability to influence others to achieve a specific goal (Dilts, 2007). Obviously, it does not mean that network leadership is not different from traditional. Many differences can be identified - it is worth pointing out that in traditional organisations control-focused leaders dominate most often, whereas in inter-organisational networks there are leaders who value self-organisation using empowerment (Kleindorfer \& Wind, 2009).

Bearing in mind the above, the authors of this article have made a subjective selection of 10 key leadership aspects worth analysing in the realities of inter-organisational networks functioning. The analysis of the identified factors was carried out in the context of the strategy dynamics characteristic for considered network systems, including two main chosen types of them - centralised and decentralised networks. The list presented below is in effect a theoretical basis for conducting planned leadership research in network systems. The research aspects of leadership selected by the authors include factors indicated in Table 5.

Among the above aspects of realising leadership in inter-organisational networks, the authors claim it is worth to pay special attention to a few of them which potentially are of key importance for the development of a network system. According to the subjective choice, one should also emphasize the importance of such aspects as building a system of efficient and fast communication between entities in the inter-organizational network, creating the atmosphere of mutual trust, loyalty and credibility, sharing the role of the leader, as well as using emotional intelligence to create lasting relationships with partners in the network. While effective communication on interpersonal and inter-organisational levels, as well as building an atmosphere of mutual trust, loyalty and credibility - seem to be an obvious basis for creating a permanent network layout, and thus are key aspects of leadership in the considered context, the next two mentioned aspects can cause more problems with interpretation.

Emotional intelligence in the classic sense presented by R. K. Cooper and A. Sawaf, is based on four pillars (Cooper \& Sawaf, 2000): emotional skills (emotional integrity, emotional energy, emotional feedback, practical intuition), emotional efficiency (authentic presence, circle of trust, constructive disagreement, resilience and renewing), emotional depth (unique potential and intentional actions, commitment, use of reliability, influence deprived of power) and emotional alchemy (flows of intuition, reflective shift in time, sensing opportunities, creating the future). In the perspective of presented considerations, the element of the emotional depth mentioned above is particularly important; namely - the influence deprived of power. Especially when network leaders are deprived of traditional tools of formal authority, recognition of emotions, mental state or the attitude of other people is fundamental for the success of cooperation within the network. It is also worth mentioning here the concept of D. Goleman, who identified as many as 6 different styles of leadership, which were supposed to be different areas of emotional intelligence - these styles are (Goleman, 2006): prescriptive, authoritative, unifying, democratic, normative and educational. The author suggested that the best leaders can combine at least 4 of the indicated styles (without prescriptive and normative ones which may harm the atmosphere of cooperation).

The aspect of sharing leadership and its spread in networks is also an increasingly common issue related to the successful inter-organisational arrangements. There is a need to accept functioning within systems in which many leaders operate at different levels of management - moving from the concept of individual leadership to current leadership is a desirable phenomenon; however, it is relatively difficult to implement (Spector, 2012). Within the discussed area, a particularly important issue is also the direct choice of own successor by leaders aware of their role and responsibility. Ensuring the continuity of strategy implementation through appropriate preparation of the successor (with the active use of the talent management system or training) should have similar validity as the business strategy itself (Lafley \& Tichy, 2012). According to the authors of this article, reliable, committed engagement and cooperation with other leaders within a specific inter-organisational network may result in a noticeable increase in the synergy effect and as a modern organisational solution should be much more strongly promoted than the need for internal competition between leaders. 
Table 5. Selected factors determining leadership in network systems and partial hypotheses assigned to them (source: own elaboration based on Harvard Business Review, 2018; Silvia \& McGuire, 2010; Goldsmith et al., 2007; Czakon, 2012; Jackson \& Morgan, 1982; Mrówka, 2010)

\begin{tabular}{|c|c|}
\hline Factor & Proposition of the hypothesis \\
\hline $\begin{array}{l}\text { Individual vs joint action in inter-organisational networks - an attempt to deter- } \\
\text { mine whether organisations in the network operate individually, pursuing their } \\
\text { interests primarily, or implement an accepted vision of joint actions, striving to } \\
\text { achieve common goals of the collective. }\end{array}$ & $\begin{array}{l}\mathrm{H} 3 \mathrm{C} 1 \text { : more centralised inter-organisa- } \\
\text { tional networks show a higher range of } \\
\text { actions in this area of joint activities }\end{array}$ \\
\hline $\begin{array}{l}\text { The regularity of strategy modification - determining whether the network strat- } \\
\text { egy remains unchanged despite changes in the environment, or rather is subject } \\
\text { to constant changes as a response to events in the environment. }\end{array}$ & $\begin{array}{l}\mathrm{H} 3 \mathrm{C} 2 \text { : more centralised networks are } \\
\text { characterised by greater dynamics of } \\
\text { strategy modification }\end{array}$ \\
\hline $\begin{array}{l}\text { Creating an atmosphere of mutual trust, loyalty, and credibility - determining } \\
\text { whether there is an atmosphere of distrust and caution within the network or ra- } \\
\text { ther an atmosphere of mutual trust that favours cooperation. }\end{array}$ & $\begin{array}{l}\text { H3C3: more centralised networks demon- } \\
\text { strate a higher level of mutual trust, } \\
\text { loyalty, and credibility }\end{array}$ \\
\hline $\begin{array}{l}\text { Building an efficient organisational communication system - an attempt to deter- } \\
\text { mine the intensity, quality and types of communication channels most frequently } \\
\text { used between entities in the network. }\end{array}$ & $\begin{array}{l}\text { H3C4: more centralised networks demon- } \\
\text { strate greater communication quality }\end{array}$ \\
\hline $\begin{array}{l}\text { Using emotional intelligence in building lasting relationships with network enti- } \\
\text { ties - establishing the level of understanding of mutual intentions, needs, emo- } \\
\text { tional states by entities representatives within the network. }\end{array}$ & $\begin{array}{l}\text { H3C5: more centralised networks are } \\
\text { characterised by a greater range of emo- } \\
\text { tional intelligence in building lasting rela- } \\
\text { tionships with network entities }\end{array}$ \\
\hline $\begin{array}{l}\text { Ways of building a strong position of network leaders - determining the primary } \\
\text { source of power in the inter-organisational network - formal or informal power. }\end{array}$ & $\begin{array}{l}\text { H3C6: a greater scope for formalising } \\
\text { power takes place in more centralised } \\
\text { networks }\end{array}$ \\
\hline $\begin{array}{l}\text { Sharing the role of the leader and delegating tasks while ensuring the necessary } \\
\text { decision-making autonomy - identifying approaches to exploiting the develop- } \\
\text { ment potential of talented employees demonstrating commitment (leadership ini- } \\
\text { tiatives) and leadership talent. }\end{array}$ & $\begin{array}{l}\text { H3C7: lower decisional autonomy and } \\
\text { delegation of tasks regards centralised net- } \\
\text { work systems }\end{array}$ \\
\hline $\begin{array}{l}\text { Respecting the adopted rules and principles, enforcing settlements, resolving in- } \\
\text { tra-network conflicts and punishing inappropriate behaviours - an attempt to de- } \\
\text { termine whether disorder and organisational chaos prevails in the examined inter- } \\
\text { organisational networks or it is rather a standard to meticulously adhere to the } \\
\text { written rules and regulations. }\end{array}$ & $\begin{array}{l}\mathrm{H} 3 \mathrm{C} 8 \text { : more centralised networks are } \\
\text { more rigid in terms of adherence to rules } \\
\text { and principles }\end{array}$ \\
\hline $\begin{array}{l}\text { Implementing monitoring and control activities to ensure optimal work pace and } \\
\text { network system performance - analysis of the use of procedures and control tools } \\
\text { - from a complete absence of them to the use of vast modern monitoring and } \\
\text { control mechanisms supported by consciously shaped skills of network members, } \\
\text { as well as modern software. }\end{array}$ & $\begin{array}{l}\text { H3C9: a higher control degree of network } \\
\text { systems concerns more centralised } \\
\text { network systems }\end{array}$ \\
\hline $\begin{array}{l}\text { Representing the network system in the socio-economic environment - an at- } \\
\text { tempt to determine whether the network has representatives consciously shaping } \\
\text { its image in the business environment. }\end{array}$ & $\begin{array}{l}\text { H3C10: more centralised networks show } \\
\text { higher activity in the area of conscious } \\
\text { image formation }\end{array}$ \\
\hline
\end{tabular}

\section{Conclusions}

The article is a continuation of work on the dynamism and dynamics of the strategy of inter-organisational networks. Its primary goal was to clarify research hypotheses in the areas of three differentiating factors, namely propensity to risk, the use of opportunities and leadership in inter-organisational networks, which the authors called the triangle of dynamics factors that are the antecedents of strategy dynamics. Such factors are the side-effects of own large research carried out at the turn of 2017 and 2018. The problem identified during the joint work of authors was located into the strategising concept, assuming that the foundations of this idea are part of the analysed issues - both the research object (inter-organisational networks) and the subject (determinants of dynamism and strategy dynamics of inter-organisational networks). The authors reserve the right to change the research hypotheses, arguing that conducted considerations are still at the initial theoretical stage - both in terms of dynamism and strategy dynamics of inter-organisational networks. Planned, future research will be firmly focused on carefully examining the three identified factors affecting strategy dynamics within inter-organisational networks' activities in order to recognise their direct influence on networks' development. It is especially recommended for other authors to involve presented issues: the propensity to risk, the use of opportunities, as well as leadership skills - regarding business networks, into their research areas. 


\section{References}

Alvarez, S. A., Barney, J. B., \& Anderson, P. (2013). Forming and exploiting opportunities: The implications of discovery and creation processes for entrepreneurial and organizational research. Organizational Science, 24(1), 304-305. https://doi.org/10.1287/orsc. 1110.0727

Baron, R. A. (2006). Opportunity recognition as pattern recognition: How entrepreneurs "Connect the Dots" to identify new business opportunities. Academy of Management Perspectives, 20(1), 104-119. https://doi.org/10.5465/amp.2006.19873412

Butler, J. E., Doktor, R., \& Lins, F. A. (2010). Linking international entrepreneurship to uncertainty, opportunity discovery, and cognition. Journal of International Entrepreneurship, 8(2), 121-134. https://doi.org/10.1007/s10843-010-0054-x

Chandra, Y., Styles, C., \& Wilkinson, I. (2009). The recognition of first time international entrepreneurial opportunities: evidence from firms in knowledge-based industries. International Marketing Review, 26(1), 30-61. https://doi.org/10.1108/02651330910933195

Chrisidu-Budnik, A. (2011). Zaufanie i wiarygodność w sieciach międzyorganizacyjnych, Prace Naukowe Uniwersytetu Ekonomicznego we Wrocławiu, 217, 63-76. Retrieved from http://yadda.icm.edu.pl/yadda/element/bwmeta1.element.ekonelement-000171204295

Cooper, R. K., \& Sawaf, A. (2000). EQ inteligencja emocjonalna w organizacji i zarzadzaniu. Studio Emka, Warszawa.

Corbett, A. C. (2007). Learning asymmetries and the discovery of entrepreneurial opportunities. Journal of Business Venturing, 22(1), 97-118. https://doi.org/10.1016/j.jbusvent.2005.10.001

Czakon, W. (2012). Sieci w zarządzaniu strategicznym. Warszawa: Wolters Kluwer.

Dilts, R. B. (2007). Przywództwo z wizją. Kreowanie świata, do którego ludzie chca przynależeć. NLP Neuroedukacja, Lublin.

Eisenhardt, K. (1989). Making fast strategic decisions in high-velocity environments. Academy of Management Journal, 32(3), 543576. https://doi.org/10.5465/256434

Gaglio, C. M., \& Katz, J. A. (2001). The psychological basis of opportunity identification: entrepreneurial alertness. Small Business Economics, 16, 95-111. https://doi.org/10.1023/A:1011132102464

Gnyawali, D. R., \& Madhavan, R. (2001). Cooperative networks and competitive dynamics: A structural embeddedness perspective. Academy of Management, 26(3), 431-445. https://doi.org/10.5465/amr.2001.4845820

Goldsmith, M., Greenberg, C. L., Robertson, A., \& Hu-Chan, M. (2007). Globalni liderzy-kolejna generacja / Global Leadership: The Next Generation. Warszawa: MT Biznes.

Goleman, D. (2006). Przywództwo, które przynosi efekty. Harvard Business Review, Atrybuty przywódcy, Helion, Gliwice.

Harvard Business Review (2018). Podręcznik menedżera. 17 najważniejszych umiejętności lidera. Poznań: Dom Wydawniczy REBIS.

Hatch, M. (2002). Teoria organizacji. Warszawa: PWN.

Jackson, J. H., \& Morgan, C. P. (1982). Organization theory. Macro perspective for management. Prentice Hall. Retrieved from https://doi.org/10.7202/029269ar

Jarzabkowski, P. (2008). Shaping strategy as a structuration process. Academy of Management Journal, 51(4), 621-650. https://doi.org/10.5465/amr.2008.33664922

Johnson, G., Melin, L., \& Whittington, R. (2003). Micro strategy and strategizing: Towards an activity-based view?. Journal of Management Studies, 40(1), 3-22. https://doi.org/10.1111/1467-6486.t01-2-00002

Jarzabkowski, P., Balogun, J., \& Seidl, D. (2007). Strategizing: The challenges of a practice perspective. Human Relations, 60(1), 5-27. https://doi.org/10.1177/0018726707075703

Kirzner, I. M. (1997). Entrepreneurial discovery and the competitive market process: an Austrian approach. Journal of Economic Literature, 35, 60-85. Retrieved from https://papers.ssrn.com/sol3/papers.cfm?abstract_id $=1505851$

Kleindorfer, P., \& Wind, Y. (2009). The Network Imperative: Community or Contagion. In P. Kleindorfer, \& Y. Wind (Eds.), The Network Challenge: Strategy, Profit, and Risk in an Interlinked World (p. 22). Upper Saddle River: Wharton School Publishing, Pearson Education. Retrieved from https://faculty.wharton.upenn.edu/wp-content/uploads/2012/05/0903 The_Network_Imperative.pdf

Lafley, G. A., \& Tichy, N. M. (2012). Niuanse poszukiwań właściwego prezesa. Harvard Business Review Polska, 110, 38-43. Retrieved from https:/www.hbrp.pl/a/niuanse-poszukiwan-wlasciwego-prezesa/LMnTS1H6

Mrówka, R. (2010). Przywództwo w organizacjach. Warszawa: Wolters Kluwer.

Muzychenko, O. (2008). Cross-cultural entrepreneurial competence in identifying international business opportunities. European Management Journal, 26(6), 366-377. https://doi.org/10.1016/j.emj.2008.09.002

Niemczyk, J. (2006). Wyróżniki, budowa i zachowania strategiczne układów outsourcingowych, Wydawnictwo Akademii Ekonomicznej im. Wrocław: Oskara Langego we Wrocławiu.

Nooteboom, B. (2005). Learning and Governance in Inter-Firm Relations, Discussion Paper, Tilburg University, Tilburg, https://doi.org/10.3917/redp.141.0055

Organa, M., \& Sus, A. (2019). Dynamics and the dynamism of strategy in inter-organizational network - research project assumptions. Springer Proceedings in Business and Economics, Contemporary problems and challenges in cooperation and competition in the age of Industry 4.0 [in press].

Palmer, R. E. (2010). Przywództwo doskonałe. Warszawa: Wolters Kluwer.

Parkhe, A. (1993). Strategic alliance structuring: A game theoretic and transaction cost examination of interfirm cooperation. The Academy of Management Journal, 36(4), 794-829. https://doi.org/10.5465/256759 
Ratajczak-Mrozek, M. (2013). Sieci a konkurencyjność i strategie przedsiębiorstw, [w:] M. Ciesielski (Ed.), Sieci w gospodarce, PWE, Warszawa.

Shane, S. (2000). Prior Knowledge and the discovery of entrepreneurial opportunities. Organization Science, 11(4), 448-469. https://doi.org/10.1287/orsc.11.4.448.14602

Shepherd, D. A., \& DeTienne, D. E. (2005). Prior knowledge, potential financial reward, and opportunity identification. Entrepreneurship Theory and Practice, 29(1), 91-112. https://doi.org/10.1111/j.1540-6520.2005.00071.x

Silvia, Ch., \& McGuire, M. (2010). Leading public sector networks: An empirical examination of integrative leadership behaviors. The Leadership Quarterly, 21, 264-277. https://doi.org/10.1016/j.leaqua.2010.01.006

Simons, R. (1999). How Risky is Your Company?. Harvard Business Review.

Spector, B. (2012). Wprowadzanie zmiany w organizacji. Warszawa: PWN.

Sus, A. (2017). Mikro - i otwarta strategia. Kontekst ekosystemu. Organizacja i Kierowanie, no 2.

Sus, A. (2019). Logika dopasowania okazji i strategicznych opcji realnych. Wrocław: Wydawnictwo Uniwersytetu Ekonomicznego we Wrocławiu [in press].

Tripsas, M. (2008). Customer preference discontinuities: a trigger for radical technological change. Managerial and Decision Economics, 29(2/3), 79-97. https://doi.org/10.1002/mde.1389

Ucbasaran, D., Westhead, P., \& Wright, M. (2009). The extent and nature of opportunity identification by experienced entrepreneurs. Journal of Business Venturing, 24(2), 99-115. https://doi.org/10.1016/j.jbusvent.2008.01.008

Williams, M. (2009). Mistrzowskie przywództwo. Kraków: Wolters Kluwer Polska.

Witt de, B., \& Meyer, R. (2007). Synteza strategii. Warszawa: PWE.

Zaheer, A., \& Zaheer, S. (1997). Catching the Wave: Alertness, Responsiveness, and Market Influence in Global Electronic Networks. Management Science, 43(11), 1493-1509. https://doi.org/10.1287/mnsc.43.11.1493

Zenger, J. H., Folkman, J. R., \& Edinger, S. K. (2012). Bądź niezastapiony. Harvard Business Review Polska. 